\title{
PENGARUH KARAKTERISTIK PERJALANAN SEKOLAH DAN MODA TRANSPORTASI YANG DIGUNAKAN TERHADAP PEMILIHAN SEKOLAH DI JABODETABEK
}

\author{
Aldo $^{1}$ dan Leksmono Suryo Putranto ${ }^{2}$ \\ ${ }^{1}$ Program Studi Sarjana Teknik Sipil, Universitas Tarumanagara, Jl. Letjen S. Parman No.1 Jakarta \\ Email:aldomch@yahoo.com \\ ${ }^{2}$ Program Studi Sarjana Teknik Sipil, Universitas Tarumanagara, Jl. Letjen S. Parman No.1 Jakarta \\ Email:lexy_putranto@yahoo.co.id
}

\begin{abstract}
ABSTRAK
Sekolah merupakan salah satu tempat pendidikan untuk belajar. Setiap individu memiliki pilihan sekolah masing - masing. Sarana dan prasarana yang lebih lengkap dari sekolah yang lain lebih diminati daripada sekolah yang memiliki sarana dan prasarana kurang lengkap atau sekolah yang letaknya strategis dan mudah dijangkau dengan kendaraan umum juga lebih diminati. Penelitian ini bertujuan untuk mengetahui kriteria pemilihan sekolah, menganalisis moda transportasi yang digunakan dan karakterisitik perjalanan sekolah. Pengumpulan data dilakukan dengan menggunakan kuesioner online (54 orang) dan offline (50 orang) terhadap individu yang mempunyai anak usia 5 -15 tahun atau anak yang bersekolah pada tahap TK sampai SMP di JABODETABEK. Metode analisis yang digunakan pada penelitian ini adalah metode one sample t-test dan analisis korelasi Pearson. Hasil penelitian menunjukan hal yang paling mempengaruhi dalam kriteria pemilihan sekolah yaitu, reputasi sekolah, keuangan orangtua, fasilitas non-akademik sekolah, dan kesempatan anak mengembangkan kreativitas dan minat khusus. Mayoritas para orangtua menggunakan kendaraan pribadi mengantar anaknya pergi ke sekolah.
\end{abstract}

Kata kunci: pilihan sekolah, transportation, karakteristik perjalanan sekolah.

\section{PENDAHULUAN}

\section{Latar Belakang}

Pendidikan adalah pembelajaran pengetahuan, keterampilan, dan kebiasaan sekelompok orang yang diturunkan dari satu generasi ke generasi berikutnya melalui pengajaran, pelatihan, atau penelitian (John, 1944). Pendidikan memiliki peranan penting dalam perjalan hidup manusia. Melalui pendidikan manusia menjadi cerdas, memiliki kemampuan, sikap dan cara hidup yang baik dan benar. Sekolah merupakan cara untuk menempuh pendidikan.

Sekolah merupakan salah satu tempat pendidikan untuk belajar yang umum digunakan oleh setiap orang. Pada saat sekarang ini sekolah bukan hanya memberikan pelayanan berupa pendidikan saja, tetapi juga bersaing untuk memberikan pelayanan yang lebih dari sekolah-sekolah lain. Hal ini bertujuan agar sekolah tersebut akan lebih diminati oleh masyarakat karena kelebihan-kelebihannya serta untuk meningkatkan image sekolah tersebut. Sebagai contoh, sekolah yang memiliki sarana dan prasarana yang lebih lengkap dari sekolah yang lain lebih diminati daripada sekolah yang memiliki sarana dan prasarana kurang lengkap atau sekolah yang letaknya strategis dan mudah dijangkau dengan kendaraan umum juga lebih diminati. Setiap individu memilih dan memutuskan sekolah sesuai kriteria yang telah ditentukan. Banyak aspek yang harus dipertimbangkan dalam pemilihan sekolah.

Dalam penelitian ini akan dianalisis kriteria apa saja yang akan dipilih oleh setiap individu, dan moda transportasi apa yang sering mereka gunakan untuk mencapai lokasi sekolah.

\section{Batasan Masalah}

1. Wilayah yang digunakan dalam penelitian ini adalah JABODETABEK (Jakarta, Bogor, Depok, Tangerang, dan Bekasi).

2. Subjek penelitian merupakan individu yang bertanggung jawab dalam pemilihan sekolah

3. Subjek penelitian merupakan individu yang mempunyai anak usia $5-15$ tahun 


\section{Rumusan Masalah}

1. Bagaimana kriteria pemilihan sekolah?

2. Bagaimana penggunaan moda transportasi dalam bersekolah?

3. Bagaimana karakteristik perjalanan sekolah?

\section{Tujuan Penelitian}

1. Mengetahui kriteria pada pemilihan sekolah.

2. Menganalisis moda transportasi yang digunakan dalam bersekolah.

3. Menganalisis karakteristik perjalanan sekolah.

\section{TINJAUAN PUSTAKA}

\section{Sekolah}

Sekolah adalah suatu lembaga untuk pengajaran siswa/murid di bawah pengawasan guru, terjadi kegiatan belajar dan mengajar di sekolah. Sebagian besar negara memiliki sistem pendidikan formal yang umumnya wajib, dalam sistem ini, siswa mengalami perkembangan melalui kegiatan belajar mengajar di sekolah. Nama-nama untuk sekolah ini bervariasi menurut negara (dibahas pada bagian Daerah di bawah), tetapi umumnya termasuk sekolah dasar untuk anak-anak muda dan sekolah menengah untuk remaja yang telah menyelesaikan pendidikan dasar. Selain sekolah inti, siswa di negara tertentu juga mungkin memiliki akses dan mengikuti sekolah baik sebelum dan sesudah pendidikan dasar dan menengah. Taman Kanak -Kanak atau pra-sekolah menyediakan sekolah bagi anakanak (biasanya umur 3-5 tahun). Universitas, sekolah kejuruan, perguruan tinggi atau seminari mungkin tersedia setelah sekolah menengah. Sebuah sekolah mungkin juga didedikasikan untuk satu bidang tertentu, seperti sekolah ekonomi atau sekolah tari. Alternatif sekolah dapat menyediakan kurikulum dan metode non-tradisional. Menurut johnsson dan lingdren (2010), ada beberapa faktor yang berkaitan dengan struktur sekolah, seperti ukuran kelas dan yang menarik bangunan sekolah (ukuran fisik sekolah).

\section{Jenis-jenis Moda Transportasi}

Jenis moda transportasi terus berkembang dari zaman ke untuk memenuhi kebutuhan bertransportasi. Jenis-jenis transportasi yang sering digunakan pada saat ini adalah :

1. Angkutan pribadi

Angkutan pribadi (private transportation) adalah moda transportasi yang dikhususkan untuk pribadi seseorang yang bebas menggunakannya kemana saja, kapan saja, dan di mana saja yang diinginkan atau tidak menggunakannya sama sekali (Simanjuntak, 2009).

2. Angkutan umum

Angkutan Umum adalah angkutan penumpang yang dilakukan dengan sistem sewa atau bayar. Termasuk dalam pengertian angkutan umum penumpang adalah: angkutan kota (bus, minibus, dsb), kereta api, angkutan air dan angkutan udara (Warpani, 1990). Sedangkan angkutan kota adalah angkutan dari suatu tempat ketempat lain dalam wilayah kota dengan menggunakan mobil bus dan atau mobil penumpang umum yang terikat dalam trayek tetap dan teratur (SK Dirjen Perhubungan Darat no. 687, 2002).

3. Angkutan online

Angkutan Jalan yang berjalan dengan mengikuti serta memanfaatkan perkembangan ilmu pengetahuan (teknologi) berbasis aplikasi dan online baik untuk pemesanan maupun pembayaran, Misalnya ojek online, taxi online, dan mobil online.

\section{Hubungan Anak dengan Sekolah dan Guru}

Sekolah dan guru tidak dapat dipisahkan, mereka adalah satu kesatuan. Siswa/siswi belajar dan menimba ilmu di sekolah pilihan mereka bersama guru. Ada beberapa faktor yang dipertimbangkan agar anak bersekolah di sekolah pillihan (Liu, 2012). Peranan pihak sekolah sangat berpengaruh dalam membentuk karakteristik anak di sekolah dan mengajarkan hal - hal positif guna berkehidupan di masyarakat (Blast dan Walberg, 2004). Sekolah bertanggung jawab atas kegiatan belajar dan mengajar, orang tua harus percaya dan mendukung anaknya dalam kegiatan belajar pada waktu dan tempat yang di percayakan. Guru bertanggung jawab atas segala hal yang telah di percayakan orang tua masing - masing siswa. Guru berperan membimbing serta mengajarkan ilmu dan etika yang baik dan benar. Tugas guru mengajar dan memperlakukan setiap siswa dengan setara, dan guru harus memperhatikan siswa dalam menyerap ilmu - ilmu yang diajarkan (Hammond dan Dennison, 1995). Sekolah dan guru menuntut siswa/siswi patuh terhadap peraturan yang telah ditetapkan di sekolah, jika ada yang melanggar siswa harus mendapatkan sanksi dan teguran dari guru karena itu merupakan bentuk hidup yang disiplin dan taat pada aturan (Echols dan Willms, 1995) 


\section{Peran Orang Tua}

Pusat pendidikan yang pertama adalah lingkungan keluarga. Masyarakat semakin menyadari pentingnya memberikan pendidikan yang terbaik kepada anak-anak mereka sejak dini (Ariyani, 2016). Sudah merupakan kewajiban para orang tua untuk menciptakan lingkungan yang kondusif sehingga dapat melihat potensi anak dan tidak lupa memahami tahap perkembangan anak serta kebutuhan pengembangan potensi kecerdasan dari setiap tahap (Chiswick, 1988). Ada banyak cara untuk memberikan pendidikan kepada anak baik formal maupun non formal. Orang tua memberikan sarana dan prasarana dalam proses pembelajaran. Selain itu pendidikan non formal mendidik anak dengan memnamkan tata nilai yang baik dan benar, budi pekerti, norma-norma, budaya, pola prilaku dan aspirasi dengan bimbingan orang tua di rumah. Jika suatu keluarga dikaruniai seorang anak, maka pada pundak orangtua itulah dibebankan usaha bagaimana agar anak-anaknya berkembang dengan baik Orang tua harus lebih memperhatikan anak-anak mereka, melihat potensi dan bakat yang ada di diri anak-anak mereka, memberikan sarana dan prasarana untuk mendukung proses pembelajaran mereka di sekolah. Para orang tua diharapkan dapat melakukan semua itu dengan niat yang tulus untuk menciptakan generasi yang mempunyai moral yang luhur dan wawasan yang tinggi serta semangat pantang menyerah.

\section{Karakteristik Perjalanan Sekolah}

Banyaknya individu yang melakukan perjalan ke sekolah setiap hari kerja menyebabkan banyaknya pola perjalanan dan karakteristik perjalanan. Sarana perangkutan mempunyai peran yang sangat penting demi memperlancar pergerakan masyarakat. Penelitian yang menjelaskan perilaku sistem yang ideal berdasarkan standar fasilitas pendidikan untuk mengetahui karakteristik siswa sebagai pelaku perjalanan. Berapa lama waktu yang dibutuhkan, berapa jarak yang ditempuh, berapa biaya yang dikeluarkan, dan fasilitas umum yang menentukan aksesibiltas perjalanan setiap individu menuju lokasi sekolah. Aksebilitas (kemudahan pencapaian), secara tidak langsung merupakan tercukupinya distribusi rute di seluruh area yang dilayani, kapasitas kendaraan, frekwensi pelayanan dan rentang waktu operasi, ciri khas pemberhentian dan kendaraan serta distribusi informasi mengenai jarak, jadwal dan lain-lain.

\section{METODOLOGI PENELITIAN}

\section{Prosedur Penelitian}

Dalam penelitian ini digunakan dua metode kuesioner yakni online dan langsung. Kuesioner langsung dibagikan kepada 50 responden. Responden dapat langsung bertanya kepada penyurvei apabila ada butir pertanyaan yang kurang jelas. Sebanyak 54 orang mengisi melalui Google Form.

Kuesioner bersisi 2 bagian utama yakni data umum dan butir pertanyaan. Pada data umum responden diminta untuk mengisi nama, jenis kelamin, usia, domisili, pendidikan terakhir, pekerjaan, status perkawinan, jumlah pengeluaran dalam satu bulan, agama, suku, kendaraan yang dimiliki dan jumlah anggota keluarga. Responden diminta untuk mengisi kuesioner mengenai aktivitas yang dilakukan, menggunakan Skala Likert dimana nilai 1 hampir tidak pernah hingga nilai 4 hampir selalu. Kemudian tingkat pertimbangan saat hendak melakukan aktivitas tersebut, disini juga menggunakan Skala Likert dimana nilai 1 menunjukkan sangat tidak setuju hingga nilai 4 menunjukkan sangat setuju. Berikut adalah pertanyaan-pertanyaan yang terdapat dalam kuesioner:

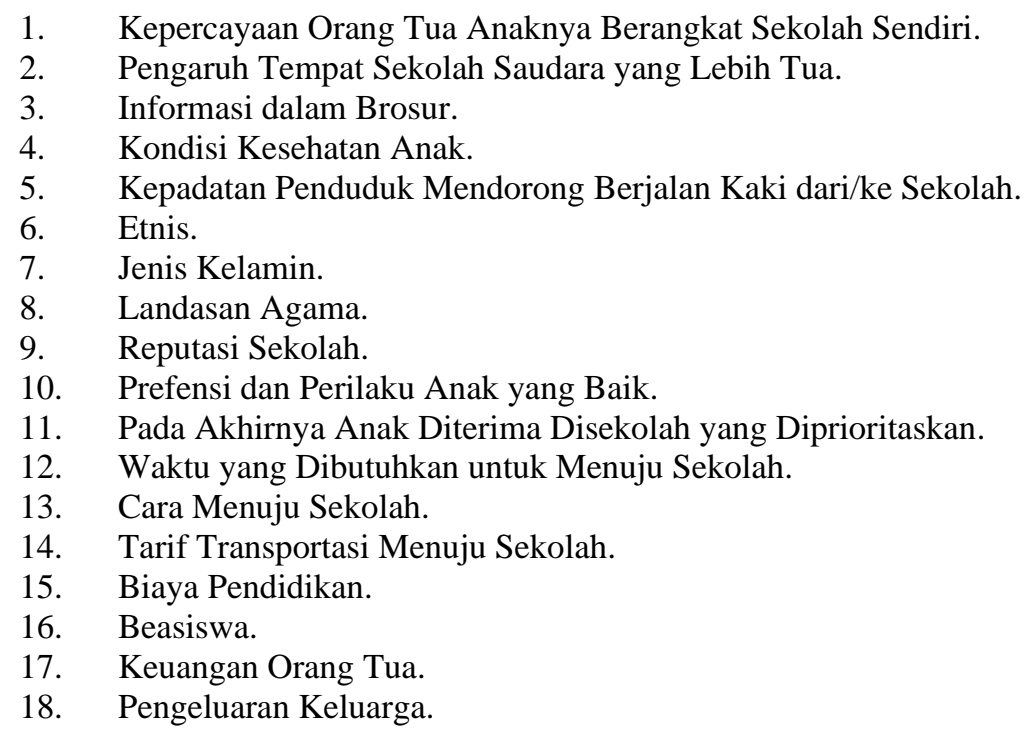


19. Biaya Transportasi.

20. Sekolah Memfasilitasi Anak Berkebutuhan Khusus.

21. Akses ke Jalan Raya, Transportasi Umum, dan Tata Ruang Berjalan dan Bersepeda

22. Fasilitas Non-Akademik

23. Fasilitas Akademik

24. Fasilitas Umum yang Dekat Sekolah

25. Kelengkapan Kelas yang Baik

26. Lokasi yang Berdekatan dengan Fasilitas dan Layanan Transportasi

27. Lokasi yang Berdekatan dengan Pusat Pembelanjaan

28. Lokasi yang Berdekatan dengan Tempat Tinggal

29. Lokasi yang Berdekatan dengan Pemukimam Penduduk

30. Jarak Tempuh

31. Tersedia Rute Aman Selamat Sekolah (RASS) dan Zona Selamat Sekolah (ZoSS)

32. Rute Berjalan Teduh pada Siang hari dan Terang pada Malam Hari

33. Lahan Parkir

34. Sekolah Negri Menjadi Pilihan Utama

35. Sekolah Swasta Menjadi Pilihan Utama

36. Sekolah Home School Menjadi Pilihan Utama

37. Sekolah Boarding School Menjadi Pilihan Utama

38. Sekolah Madrasah Menjadi Pilihan Utama

39. Sekolah Kejuruan Menjadi Pilihan Utama

40. Sekolah Dwi Bahasa Menjadi Pilihan Utama

41. Nilai - Nilai dan Keyakinan Berasama Serta Gaya Mengajar

42. Jumlah Siswa Perkelas

43. Layanan Sekolah Diluar Jam Kegiatan Mengajar

44. Kelengkapan Jenjang Pendidikan

45. Pengembangan Minat dan Kreativitas Anak

Pertanyaan nomor 1-14 termasuk dalam aspek sosial dan budaya. 15-19 termasuk dalam aspek ekonomi. 20-33 termasuk dalam aspek fisik sekolah. 34-45 termasuk dalam aspek non-fisik sekolah.

\section{ANALISIS DATA}

\section{Rangkuman Data Penelitian}

Tabel 1. Nilai Minimal, Nilai Maksimal dan Rataan Dari Hasil Rekapitulasi Aspek Sosial dan Budaya

\begin{tabular}{|c|c|c|c|c|}
\hline No & Indikator & Minimum & Maksimum & Rataan \\
\hline 1 & $\begin{array}{l}\text { Apakah orang tua percaya bahwa anaknya dapat } \\
\text { berangkat sekolah sendiri? }\end{array}$ & 1 & 4 & 2,80 \\
\hline 2 & $\begin{array}{l}\text { Apakah pilihan sekolah dipengaruhi di tempat } \\
\text { sekolah anak yang lebih tua? }\end{array}$ & 1 & 4 & 2,82 \\
\hline 3 & $\begin{array}{l}\text { Dapatkah informasi dalam brosur sekolah } \\
\text { membantu mengambil keputusan pilihan } \\
\text { sekolah? }\end{array}$ & 1 & 4 & 2,91 \\
\hline 4 & $\begin{array}{l}\text { Apakah kondisi kesehatan anak mempengaruhi } \\
\text { pilihan sekolah? }\end{array}$ & 1 & 4 & 2,90 \\
\hline 5 & $\begin{array}{l}\text { Apakah kepadatan penduduk mendorong } \\
\text { perilaku berjalan kaki ke/dari sekolah? }\end{array}$ & 1 & 4 & 2,80 \\
\hline 6 & Apakah etnis mempengaruhi pemilihan sekolah? & 1 & 4 & 2,66 \\
\hline 7 & $\begin{array}{l}\text { Apakah jenis kelamin mempengaruhi pemilihan } \\
\text { sekolah? }\end{array}$ & 1 & 4 & 2,69 \\
\hline 8 & $\begin{array}{l}\text { Apakah sekolah yang dilandaskan pada agama } \\
\text { tertentu mempengaruhi pemilihan sekolah? }\end{array}$ & 1 & 4 & 2,91 \\
\hline 9 & $\begin{array}{l}\text { Apakah reputasi sekolah mempengaruhi pilihan } \\
\text { sekolah? }\end{array}$ & 2 & 4 & 3,44 \\
\hline 10 & $\begin{array}{l}\text { Apakah preferensi dan perilaku siswa yang baik } \\
\text { mempengaruhi pilihan sekolah? }\end{array}$ & 2 & 4 & 3,30 \\
\hline 11 & $\begin{array}{l}\text { Apakah pada akhirnya, anak diterima disekolah } \\
\text { yang diprioritaskan? }\end{array}$ & 1 & 4 & 3,07 \\
\hline
\end{tabular}


Terlihat bahwa semua indikator pada aspek sosial dan budaya memiliki nilai rataan lebih dari 2,5 yang mengindikasikan bahwa sebagian besar responden setuju dengan pernyataan yang telah disebutkan. Untuk indikator reputasi sekolah dan indikator prefensi dan perilaki siswa yang baik sebagian responden sangat setuju dengan pernyataan tersebut denga nilai rataan lebih dari 3. Dan nilai rataan paling rendah yaitu indikator etnis dengan nilai rataan 2,66 .

Tabel 2. Nilai Minimal, Nilai Maksimal dan Rataan Dari Hasil Rekapitulasi Aspek Ekonomi

\begin{tabular}{clccc}
\hline No & \multicolumn{1}{c}{ Indikator } & Minimum & Maksimum & Rataan \\
\hline 1 & $\begin{array}{l}\text { Apakah biaya pendidikan menjadi pertimbangan } \\
\text { pilihan sekolah? }\end{array}$ & 2 & 4 & 3,11 \\
\hline 2 & $\begin{array}{l}\text { Apakah beasiswa menjadi pertimbangan pilihan } \\
\text { sekolah? }\end{array}$ & 1 & 4 & 2,59 \\
\hline 3 & $\begin{array}{l}\text { Apakah keuangan orang tua mempegaruhi } \\
\text { pemilihan sekolah? }\end{array}$ & 2 & 4 \\
\hline 4 & $\begin{array}{l}\text { Apakah pengeluaran keuangan anggota keluarga } \\
\text { yang lain mempengaruhi pemilhan sekolah? }\end{array}$ & 1 & 4,12 \\
\hline 5 & $\begin{array}{l}\text { Apakah biaya transportasi mempengaruhi } \\
\text { pemilihan sekolah? }\end{array}$ & 4 & 2,74 \\
\hline
\end{tabular}

Terlihat bahwa semua indikator pada aspek ekonomi memiliki nilai rataan lebih dari 2,5 yang mengindikasikan bahwa sebagian besar responden setuju dengan pernyataan yang telah disebutkan. Untuk indikator biaya pendidikan, indikator keuangan orang tua, dan indikator pengeluaran keuangan anggota keluarga sebagian responden sangat setuju dengan pernyataan tersebut denga nilai rataan lebih dari 3. Dan nilai rataan paling rendah yaitu indikator beasiswa dengan nilai rataan 2,59 .

Tabel 3. Jumlah Data, Nilai Minimal, Nilai Maksimal dan Rataan Dari Hasil Rekapitulasi Aspek Fisik Sekolah

\begin{tabular}{|c|c|c|c|c|}
\hline No & Indikator & Minimum & Maksimum & Rataan \\
\hline 1 & $\begin{array}{l}\text { Apakah sekolah memfasilitasi anak-anak } \\
\text { berkebutuhan khusus mempengaruhi pemilihan } \\
\text { sekolah? }\end{array}$ & 1 & 4 & 2,43 \\
\hline 2 & $\begin{array}{l}\text { Apakah akses ke jalan raya, transportasi umum, dan } \\
\text { tata ruang berjalan dan bersepeda mempengaruhi } \\
\text { lokasi sekolah yang anda pilih? }\end{array}$ & 1 & 4 & 3,07 \\
\hline 3 & $\begin{array}{l}\text { Apakah fasilitas non - akademik mempengaruhi } \\
\text { pemilihan sekolah? }\end{array}$ & 1 & 4 & 3,18 \\
\hline 4 & $\begin{array}{l}\text { Apakah fasilitas akademik mempengaruhi } \\
\text { pemilihan sekolah? }\end{array}$ & 1 & 4 & 3,17 \\
\hline 5 & $\begin{array}{l}\text { Apakah fasilitas umum yang lenkap dekat sekolah } \\
\text { mempengaruhi pemilihan sekolah? }\end{array}$ & 1 & 4 & 3,08 \\
\hline 6 & $\begin{array}{l}\text { Apakah kelengkapan kelas mempengaruhi } \\
\text { pemilihan sekolah? }\end{array}$ & 1 & 4 & 3,07 \\
\hline 7 & $\begin{array}{l}\text { Apakah lokasi yang berdekatan dengan fasilitas dan } \\
\text { layanan transportasi mempengaruhi pemilihan } \\
\text { sekolah? }\end{array}$ & 1 & 4 & 2,97 \\
\hline 8 & $\begin{array}{l}\text { Apakah lokasi yang berdekatan dengan pusat } \\
\text { pembelanjaan mempengaruhi pemilihan sekolah? }\end{array}$ & 1 & 4 & 2,25 \\
\hline 9 & $\begin{array}{l}\text { Apakah lokasi yang berdekatan dengan tempat } \\
\text { tinggal mempengaruhi pemilihan sekolah? }\end{array}$ & 1 & 4 & 2,88 \\
\hline 10 & $\begin{array}{l}\text { Apakah lokasi yang berdekatan dengan pemukiman } \\
\text { penduduk mempengaruhi pemilihan sekolah? }\end{array}$ & 1 & 4 & 2,93 \\
\hline
\end{tabular}

Terlihat bahwa hampir semua indikator pada aspek fisik sekolah memiliki nilai rataan lebih dari 2,5 yang mengindikasikan bahwa sebagian besar responden setuju dengan pernyataan yang telah disebutkan, kecuali indikator sekolah memfasilitasi anak berkebutuhan khusus dengan nilai rataan 2,43 dan indikator lokasi yang berdekatan dengan pusat pembelanjaan dengan nilai rataan 2,25 juga merupakan nilai rataan paling rendah untuk aspek fisik sekolah. 

yang Digunakan Terhadap Pemilihan Sekolah di Jabodetabek

Tabel 4. Nilai Minimal, Nilai Maksimal dan Rataan Dari Hasil Rekapitulasi Aspek Non-Fisik Sekolah

\begin{tabular}{|c|c|c|c|c|}
\hline No & Indikator & Minumum & Maksimum & Rataan \\
\hline 1 & $\begin{array}{l}\text { Apakah jenis sekolah negri mempengaruhi } \\
\text { pemilihan sekolah menjadi pilihan utama? }\end{array}$ & 1 & 4 & 2,48 \\
\hline 2 & $\begin{array}{l}\text { Apakah jenis sekolah swasta mempengaruhi } \\
\text { pemilihan sekolah menjadi pilihan utama? }\end{array}$ & 1 & 4 & 3,02 \\
\hline 3 & $\begin{array}{l}\text { Apakah jenis sekolah home school mempengaruhi } \\
\text { pemilihan sekolah menjadi pillihan utama? }\end{array}$ & 1 & 4 & 1,59 \\
\hline 4 & $\begin{array}{l}\text { Apakah jenis sekolah boarding school } \\
\text { mempengaruhi pemilihan sekolah menjadi pillihan } \\
\text { utama? }\end{array}$ & 1 & 3 & 1,74 \\
\hline 5 & $\begin{array}{l}\text { Apakah jenis sekolah madrasah mempengaruhi } \\
\text { pemilihan sekolah menjadi pillihan utama? }\end{array}$ & 1 & 3 & 1,59 \\
\hline 6 & $\begin{array}{l}\text { Apakah jenis sekolah kejuruan mempengaruhi } \\
\text { pemilihan sekolah menjadi pilihan utama? }\end{array}$ & 1 & 3 & 1,86 \\
\hline 7 & $\begin{array}{l}\text { Apakah jenis sekolah dwi bahasa mempengaruhi } \\
\text { pemilihan sekolah menjadi pilihan utama? }\end{array}$ & 1 & 3 & 2,23 \\
\hline 8 & $\begin{array}{l}\text { Apakah nilai-nilai dan keyakinanan bersama serta } \\
\text { gaya mengajar mempengaruhi pilihan sekolah? }\end{array}$ & 1 & 4 & 2,88 \\
\hline 9 & $\begin{array}{l}\text { Apakah jumlah siswa perkelas mempengaruhi } \\
\text { pemilihan sekolah? }\end{array}$ & 1 & 4 & 2,56 \\
\hline 10 & $\begin{array}{l}\text { Apakah layanan sekolah diluar kegiatan mengajar } \\
\text { mempengaruhi pemilihan sekolah? }\end{array}$ & 1 & 4 & 2,85 \\
\hline 11 & $\begin{array}{l}\text { Apakah kelengkapan jenjang pendidikan dari paling } \\
\text { rendah (Taman bermain) hingga paling atas (SMA) } \\
\text { dalam satu lingkungan mempengaruhi pilihan } \\
\text { sekolah? }\end{array}$ & 1 & 4 & 2,95 \\
\hline 12 & $\begin{array}{l}\text { Apakah kesempatan mengembangkan kreativitas } \\
\text { dan minat khusus mempengaruhi pilihan sekolah? }\end{array}$ & 2 & 4 & 3,15 \\
\hline
\end{tabular}

Terlihat bahwa hampir semua indikator pada aspek non-fisik sekolah memiliki nilai rataan lebih dari 2,5 yang mengindikasikan bahwa sebagian besar responden setuju dengan pernyataan yang telah disebutkan. Namun sebagian besar responden tidak setuju dengan pernyataan mengenai sekolah negri menjadi pilhan utama, sekolah home school menjadi pilihan utama, sekolah boarding school menjadi pilihan utama, sekolah madrasah menjadi pilihan utama, sekolah kejuruan menjadi pilihan utama, dan sekolah dwi bahasa menjadi pilihan utama, terlihat nilai rataan kurang dari 2,5.

\section{Analisis Data Menggunakan Korelasi Pearson}

Secara umum Aspek Ekonomi berkorelasi secara signifikan pada $\alpha<0,05$ kecuali pada Indikator Biaya Pendidikan dan Biaya Transportasi tidak berkorelasi signifikan pada $\alpha<0,05$.

Tabel 5. Korelasi Aspek Ekonomi dengan Agama; N = 104

\begin{tabular}{lccc}
\hline \multicolumn{1}{c}{ Aspek Ekonomi } & $\begin{array}{c}\text { Koefisien } \\
\text { Korelasi (R) }\end{array}$ & $\boldsymbol{\alpha}$ & $\begin{array}{c}\text { Signifikan Pada } \\
\mathbf{\alpha} \leq \mathbf{0 , 0 5} \\
(\text { Ya/Tidak?) }\end{array}$ \\
\hline Biaya Pendidikan & $-0,013$ & 0,446 & Tidak \\
Beasiswa & 0,238 & 0,007 & Ya \\
Keuangan Orang Tua & $-0,215$ & 0,014 & Ya \\
Pengeluaran Keluarga & $-0,188$ & 0,028 & Ya \\
Biaya Transportasi & $-0,085$ & 0,196 & Tidak \\
\hline
\end{tabular}

Dapat disimpulkan bahwa :

1. Responden yang beragama selain kristen-katolik lebih dipengaruhi beasiswa dalam pemilihan sekolah dibandingkan dengan responden yang beragama kritsten-katolik.

2. Responden yang beragama kristen-katolik lebih dipengaruhi keuangan orang tua dalam pemilihan sekolah dibandingkan dengan responden yang beragama selain kritsten-katolik. 
3. Responden yang beragama kristen-katolik lebih dipengaruhi pengeluaran keluarga dala pemilihan sekolah dibandingkan dengan responden yang beragama selain kristen-katolik.

Secara umum Aspek Non-Fisik Sekolah tidak berkorelasi secara signifikan pada $\alpha<0,05$, kecuali pada indikator Sekolah Negri Menjadi Pilihan Utama dan Sekolah Madrasah Menjadi Pilihan Utama berkorelasi signifikan pada $\alpha$ $<0,05$.

Tabel 6. Korelasi Pearson Aspek Non-Fisik Sekolah dengan Usia

\begin{tabular}{lccc}
\hline \multicolumn{1}{c}{ Aspek Non-Fisik Sekolah } & Koefisien & & Signifikan Pada \\
& Korelasi (R) & $\boldsymbol{\alpha}$ & $\mathbf{\alpha} \leq \mathbf{0 , 0 5}$ (Ya/Tidak?) \\
\hline Sekolah Negri Menjadi Pilihan Utama & $-0,191$ & 0,026 & Ya \\
Sekolah Swasta Menjadi Pilihan Utama & 0,084 & 0,197 & Tidak \\
Sekolah Home School Menjadi Pilihan Utama & $-0,130$ & 0,094 & Tidak \\
Sekolah Boarding School Menjadi Pilihan Utama & $-0,133$ & 0,089 & Tidak \\
Sekolah Madrasah Menjadi Pilihan Utama & $-0,172$ & 0,041 & Ya \\
Sekolah Kejuruan Menjadi Pilihan Utama & $-0,161$ & 0,051 & Tidak \\
Sekolah Dwi Bahasa Menjadi Pilihan Utama & $-0,089$ & 0,188 & Tidak \\
Nilai - Nilai dan Keyakinan Berasama Serta Gaya & 0,080 & 0,210 & Tidak \\
Mengajar & 0,004 & 0,485 & Tidak \\
Jumlah Siswa Perkelas & 0,103 & 0,149 & Tidak \\
Layanan Sekolah Diluar Jam Kegiatan Mengajar & 0,144 & 0,072 & Tidak \\
Kelengkapan Jenjang Pendidikan & 0,137 & 0,082 & Tidak \\
Pengembangan Minat dan Kreativitas Anak & & & \\
\hline
\end{tabular}

Dapat disimpulkan bahwa :

1. Semakin muda usia responden, maka sekolah negri semakin mempengaruhi pemilihan sekolah.

2. Semakin muda usia responden, maka sekolah madrasah semakin mempengaruhi pemilihan sekolah.

\section{KESIMPULAN}

Berdasarkan hasil penelitian yang dilakukan dapat disimpulkan sebagai berikut :

1. Kriteria pemilihan sekolah:

- Aspek Sosial budaya : Reputasi sekolah yang paling mempengaruhi responden dalam pemilihan sekolah.

- $\quad$ Aspek Ekonomi : Keuangan orang tua yang paling mempengaruhi responden dalam pemilihan sekolah. Responden yang beragama kristen-katolik lebih dipengaruhi keuangan orang tua dalam pemilihan sekolah dibandingkan dengan responden yang beragama selain kritsten-katolik.

- $\quad$ Aspek Fisik Sekolah : Fasilitas non-akademik sekolah yang paling mempengaruhi responden dalam pemilihan sekolah. Semakin tua usia responden, maka fasilitas non-akademik semakin mempengaruhi dalam pemilihan sekolah.

- $\quad$ Aspek Non-Fisik sekolah : Kesempatan mengembangkan kreativitas dan minat khusus yang paling mempengaruhi responden dalam pemilihan sekolah.

2. Kendaraan pribadi yang mayoritas digunakan menuju sekolah karena orang tua tidak perlu khawatir anaknya pergi ke sekolah serta memberikan rasa nyaman dan aman. Sedangkan untuk penggunaan kendaraan umum yang paling sering digunakan adalah transportasi online. Hal tersebut bisa disebabkan oleh, kemudahan saat menggunakan, dan harga yang relatif terjangkau.

3. Karakteristik perjalanan sekolah:

- Sebagian besar waktu tempuh menuju sekolah adalah 10 menit - 30 menit.

- Sebagian besar jarak tempuh menuju sekolah adalah $1 \mathrm{KM}-5 \mathrm{KM}$.

- Sebagian besar biaya transportasi menuju sekolah adalah 10.000 rupiah - 20.000 rupiah. 
- Sebagian besar responden memiliki kendaraan mobil, dan menggunakan kendaraan pribadi untuk menuju sekolah.

\section{SARAN}

\section{Saran Pemanfaatan Penelitian}

Berdasarkan penelitian dan penarikan kesimpulan yang telah dilakukan dapat direkomendasikan saran terhadap pemanfaatan penelitian ini, yaitu, sebaiknya transportasi yang digunakan untuk menuju sekolah yaitu kendaraan umum karena bisa mengurangi kemacetan, polusi udara, dan hemat biaya. Untuk meningkatkan penggunaan transportasi umum, pemerintah lebih memperbaiki keselamatan transportasi sekolah dalam segala usia demi keamanan, keselamatan, dan kenyamanan.

\section{Saran Untuk Penelitian Selanjutnya}

Berdasarkan penelitian yang sudah dilakukan dapat direkomendasikan saran terhadap penelitian selanjutnya, yakni:

1. Dikarenakan tidak ada perbedaan hasil antara pengumpulan data secara langsung dengan online, maka kedepannya disarankan menggunakan penyebaran kuesioner secara online, karena kuesioner online lebih mudah dan cepat dalam pengumpulan data.

2. Pada kuisioner yang digunakan pada skipsi ini pada aspek sosial dan budaya di bagian cara menuju sekolahnya berbentuk jawaban terbuka sehingga seharusnya responden bisa menjawab lebih dari 1 jawaban. Tidak semua responden menulis seluruh alternatif cara menuju sekolah. Oleh sebab itu pada kuisioner perlu ditambahkan keterangan bahwa dapat mengisi lebih dari 1 cara menuju sekolah.

\section{DAFTAR PUSTAKA}

Kamus Besar Bahasa Indonesia. [Online]. Tersedia di https://kbbi.web.id/transportasi. Diakses 20 febuari 2019

---------------. Cara menghitung uji validitas dan uji reliabilitas dengan spss. Tersedia di http://qmc.binus.ac.id/2014/11/01/u-j-i-v-a-1-i-d-i-t-a-s-d-a-n-u-j-i-r-e-l-i-a-b-i-l-i-t-a,-s/. $\quad$ Diakses 20 Februari 2019.

Asadullah, M. N. (2016). "Do Pro-Poor Schools Reach Out to the Poor? Location Choice of BRAC and ROSC Schools in Bangladesh". The Australian Economic Review, 49(4), 432-52.

Dewey, J. (1944). Democracy and Education. The Free Press. Hal. 1-4.

Dustan, A. (2018). "Family Networks and School Choice". Journal of Development Economics, 134, $372-391$.

Ely, T. L. dan Teske, P. (2014). "Implications of Public School Choice for Residential Location Decisions". Urban Affairs Review 2015, 51, $175-204$.

Jacobs, N. (2011). "Understanding School Choice: Location as a Determinant of Charter School Racial, Economic, and Linguistic Segregation". Education and Urban Society 45, 4, 459-482.

Johnsson, M. dan Lindgren, J. (2010). "Great Location, Beautiful Surroundings! Making Sense of Information Materials Intended as Guidance for School Choice”. Scandinavian Journal of Educational Research, 54, 173-187.

Keats, A. (2018). “Women's Schooling, Fertility, and Child Health Outcomes: Evidence from Uganda's Free Primary Education Program". Journal of Development Economics, 142 - 159.

McDonald, N. C. (2007). "Children's Mode Choice for The School Trip: The Role of Distance and School Location in Walking to School". Transportation, 35, 23-35.

Muller, S., Haase, K., Kless, S. (2009). "A Multiperiod School Location Planning Approach with Free School Choice". Environment and Planning A 2009, 41, 2929 - 2945.

Muller, S., Haase, K. (2013). "Management of school locations allowing for free school choice". Omega, 41, 847855 .

Nayazri, G. M. (2011). Berkendara di Jalan, Ingat Ada Zona Aman Sekolah. Jakarta: Kompas.

Snow, N. B. dan Lutz, B. F. (2011). "School Desegregation, School Choice, and Changes in Residential Location Patterns by Race". American Economic, 101, 3019-3046.

Theobald, R. (2008). "School Choice in Colorado Springs: The Relationship Between Parental Decisions, Location and Neighbourhood Characteristics". International Research in Geographical \& Environmental Education, $14,92-111$.

Zhan, C. (2015). "School and Neighborhood: Residential Location Choice of Immigrant Parents in The Los Angeles Metropolitan Area”. J Popul Econ, 28, 737-783. 